\title{
Analysis of circulating immune complexes from patients with ankylosing spondylitis by gel electrophoresis and immunoblotting using antiserum against a psoriasis associated retrovirus-like particle
}

\author{
EYVIND RØDAHL AND OLE - JAN IVERSEN
}

From the Department of Microbiology, Faculty of Medicine, University of Trondheim, N-7000 Trondheim, id Norway

SUMMARY Circulating immune complexes (CIC) were isolated from patients with ankylosing음 spondylitis (AS) and healthy blood donors by isopycnic ultracentrifugation in sucrose gradients. $\rightarrow$ The CIC were analysed by sodium dodecyl sulphate-polyacrylamide gel electrophoresis $Z$ (SDS-PAGE) and immunoblotting. The major components of the CIC were identified as albumin, immunoglobulins, and complement factors. A $70 \mathrm{kD}$ component and several low molecular weight components $\left(\mathrm{M}_{\mathrm{r}} 19 \mathrm{kD}\right.$ and $14 \mathrm{kD}$ (doublet)) were detectable only in CIC from $\stackrel{\Phi}{-}$ patients with AS. An antiserum raised against the envelope glycoprotein, gp70, of a psoriasis $\overrightarrow{0}$ associated retrovirus-like particle was applied to check for cross reacting activity. This antiserum reacted with both a $70 \mathrm{kD}$ and a $40-45 \mathrm{kD}$ component in CIC from three out of six patients bet not with CIC from any of the blood donors.

Key words: isopycnic ultracentrifugation, silver staining, antigen characterisation, envelope $\stackrel{\rho}{0}^{2}$ glycoprotein.

Circulating immune complexes (CIC) are frequently detected in patients with chronic inflammatory disorders, ${ }^{1}$ including ankylosing spondylitis (AS). ${ }^{2}{ }^{3}$ Characterisation of the immune complex antigens has been desirable in order to identify antigens that may elicit the inflammatory reaction in affected tissues. Several investigators have attempted to identify immune complex antigens. ${ }^{4-7}$

The aetiology of most chronic inflammatory disorders of man is, however, still unknown. In goats and cats disorders closely resembling rheumatoid arthritis have been observed as a consequence of retrovirus infections. ${ }^{89}$ In inbred strains of mice (NZBxW, male BXSB, MRL/1) endogenous retroviruses participate in the pathogeneis of chronic arthritis ${ }^{10}$ and a systemic lupus erythematosus (SLE)

Accepted for publication 2 May 1986.

Correspondence to Dr Eyvind Rødahl, Department of Microbiology, University Hospital, N-7000 Trondheim, Norway. like disorder ${ }^{11}$ characterised among others by im mune complex formation with viral envelope glycoprotein, gp70.

Previously we have described the isolation of 20 retrovirus-like particle which was composed of a $7 Q^{\circ}$ $\mathrm{kD}$ surface glycoprotein (gp70) and three internab proteins with molecular weights of $27 \mathrm{kD}$ (p27), $15 ₹$ $\mathrm{kD}$ (p15), and $12 \mathrm{kD}$ (p12) from a patient with psoriasis. ${ }^{12-14}$ Evidence has been presented for the participation of particle antigens in the disease process in psoriasis. ${ }^{15-17}$ Recently, we also described the expression of antigens cross reacting with the psoriasis associated retrovirus-like particle in $\mathrm{pa} N$ tients with AS. ${ }^{18}$

In AS very little information has been provided with respect to a molecular characterisation of the antigens participating in the formation of CIC. Ir this report we have analysed $\mathrm{CIC}$ preparations frome patients with AS for the identification of patiento related components. Among these we were able t $\ddot{\infty}$ 892 
identify a $70 \mathrm{kD}$ antigen reacting with antiserum against the envelope glycoprotein, gp70, of the psoriasis associated retrovirus-like particle.

\section{Materials and methods}

\section{CLINICAL SPECIMENS}

Sera were obtained from 10 patients with ankylosing spondylitis. All patients were HLA-B27 positive and fulfilled the New York criteria for ankylosing spondylitis. Sera were also collected from 10 healthy blood donors. The blood donors were HLA-B27 negative.

\section{ISOLATION OF CIRCULATING IMMUNE COMPLEXES}

Serum immune complexes were isolated by isopycnic ultracentrifugation in $20-65 \%(\mathrm{w} / \mathrm{w})$ sucrose gradients as described previously. ${ }^{219}$ Fractions were collected with continuous monitoring of the absorbance at $280 \mathrm{~nm}$. The amount of IgG and IgM in gradient fractions was determined in single radial immunodiffusion using commercial immunoplates (Behringwerke AG). The gradient fractions were assayed for the presence of immune complexes by the anti-C3 enzyme linked immunosorbent assay (anti-C3 ELISA). ${ }^{20}$

\section{GEL ELECTROPHORESIS}

Gradient fractions containing immune complexes were dialysed against $0.01 \mathrm{M}$ phosphate buffer $\mathrm{pH}$ 7.0 containing $1 \%$ SDS. The protein concentration of the fractions was determined by recording the absorbance at $280 \mathrm{~nm}$ using measured amounts of human immunoglobulins (Kabi) as standard.

Mercaptoethanol (Bio-Rad) and glycerol were added to the samples to $1 \%$ and $10 \%$, respectively. Bromophenol blue served as a tracking dye. A corresponding amount of protein was applied from each sample. Standard proteins (Bio-Rad) were run in parallel lanes. The sodium dodecyl sulphatepolyacrylamide gel electrophoresis (SDS-PAGE) was performed in $30 \mathrm{~cm}$ slab gels containing $12.5 \%$ acrylamide at $30 \mathrm{~mA}$ continuous current. ${ }^{21}$

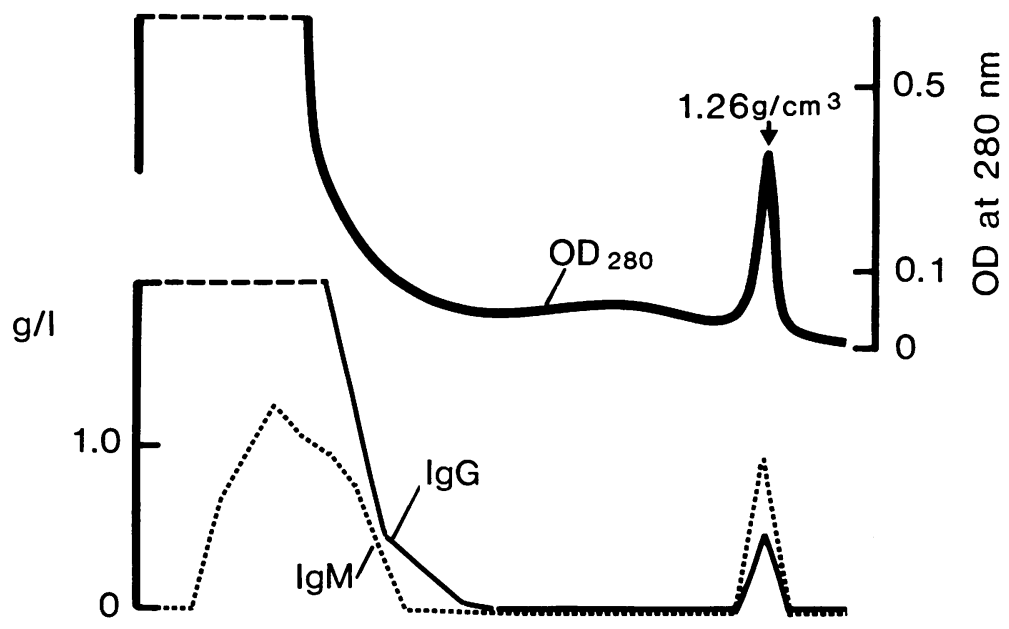

Fig. 1 Isolation of serum immune complexes from a patient with $A S$ by isopycnic ultracentrifugation. Gradient fractions were collected with continuous monitoring of the optical density at $280 \mathrm{~nm}\left(O D_{280}\right)$. IgG and IgM were measured by single radial immunodiffusion. The presence of immune complexes in the banding area is

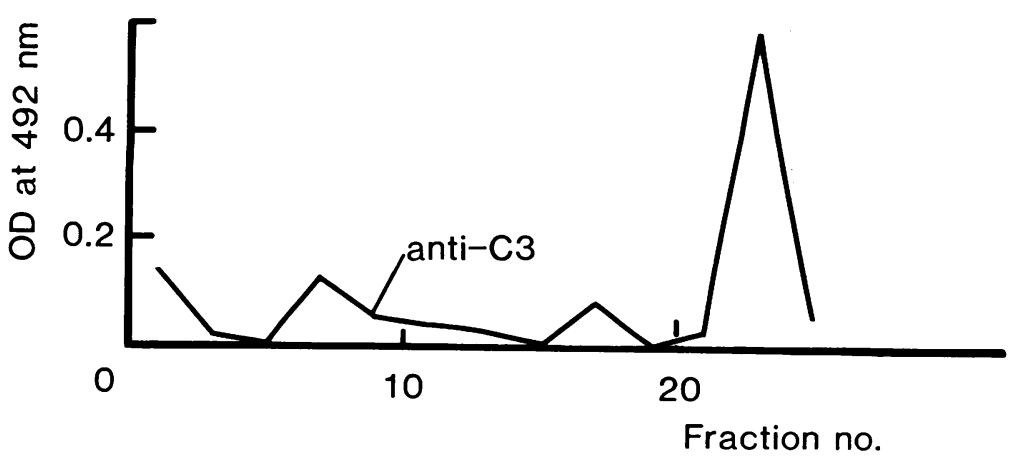
indicated by the anti-C3 ELISA. 
STAINING OF POLYACRYLAMIDE GELS

The polyacrylamide gels were stained with silver using the procedure recommended by the manufacturer (Bio-Rad), followed by staining with Coomassie brilliant blue R-250.

\section{A N T I S E R A}

Antisera against the following human proteins were applied for the characterisation of components present in the CIC preparations: Rabbit antialbumin (Behringwerke AG), peroxidase conjugated rabbit antibodies against IgM ( $\mu$ chain) (DAKO), rabbit anti-IgA ( $\alpha$ chain) (Behringwerke AG), rabbit anti-IgG (Fc fragment) (Behringwerke AG), mouse monoclonal anti-kappa light chains (Becton Dickinson), mouse monoclonal antilambda light chains (Becton Dickinson), $F\left(a^{\prime}\right)_{2}$ fragments of goat anti-C3 (Cappel Lab.), rabbit anti-C1q (DAKO), rabbit anti-C reactive protein (anti-CRP) (Behringwerke AG), rabbit anti- $\beta_{2}$ microglobulin (DAKO), and rabbit anti-fibrinogen (Behringwerke AG). Normal rabbit serum served as a control. Peroxidase conjugated antibodies against mouse, rabbit, or goat immunoglobulins (DAKO) served as second antibodies.

In addition, rabbit antiserum against the enveloped glycoprotein, gp70, of a psoriasis associated retrovirus-like particle was applied. The retroviruslike particles were isolated from urine by sucrose gradient ultracentrifugation. The glycoprotein, gp70, was purified by affinity chromatography on a Con A-Sepharose column (Pharmacia) followed by immunosorbent chromatography. Rabbits were immunised with gp70 obtained from 4 litres of urine. The testing for antibody specificity was performed with a radioimmunoassay. ${ }^{14}$

I M M U NOB L OT T IN G

Electrophoretic transfer of proteins from polyacrylamide gels to nitrocellulose membranes (Schleicher and Schüll) was performed in a Bio-Rad Trans Blot cell containing $25 \mathrm{mM}$ sodium phosphate buffer $\mathrm{pH}$ 6.5 at $20 \mathrm{~V}$ for $18 \mathrm{~h}$. The nitrocellulose membrane was cut into strips, and the standard proteins were stained with amidoblack. The strips were washed with phosphate buffered saline $\mathrm{pH} 7 \cdot 2$ containing $3 \%$ Tween 20 (PBS-3T20) for two hours, followed by incubation with antisera or normal rabbit serum diluted in PBS-3T20 for two hours. All steps were followed by thorough washing with PBS-3T20. The binding of the primary antibodies was detected by incubating the strips for two hours with peroxidase conjugated second antibodies diluted 1:1000 in PBS-3T20. For the colour reaction the blots were incubated with $40 \mathrm{mg}$ diaminobenzidine in $100 \mathrm{ml}$ of $0 \cdot 1 \mathrm{M}$ citrate-phosphate buffer $\mathrm{pH} 5.0$ containing $0.03 \% \mathrm{H}_{2} \mathrm{O}_{2}$.

\section{Results}

IS OLATION OF CIC

Sera from 10 patients with AS and sera from $10 \stackrel{\overline{\bar{\rho}}}{\mathrm{s}}$ blood donors were subjected to isopycnic ultracentrifugation. Gradient fractions were col-흘 lected with continuous monitoring of the absorbances at $280 \mathrm{~nm}$. The fractions were assayed for the
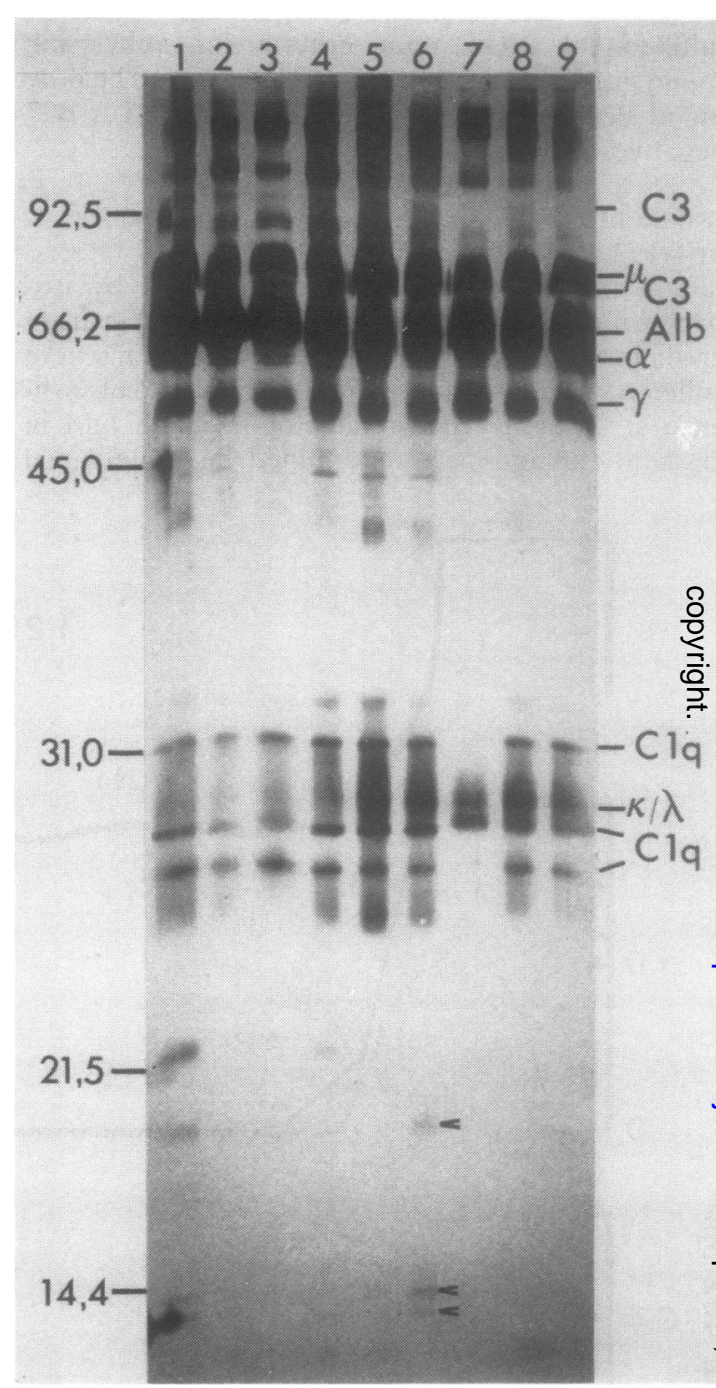

Fig. $2 S D S-P A G E$ of CIC from patients with AS (lanes 1-6) and healthy blood donors (lanes 7-9). The protein bands were visualised by silver staining. Arrows indicate low molecular weight components detectable only in CIC from patients with AS. The position and molecular weights of the standard proteins are shown on the left margin. The position of the protein bands reacting with the antisera depicted in Fig. 4 is shown on the right margin. 
presence of IgG, IgM, and complement fixing CIC. A distinct band containing CIC (Fig. 1) was formed in the gradients after centrifugation of six out of 10 sera from patients with AS and three out of 10 sera from the blood donors. The density of the fractions comprising the banding area was $1.24-1.26 \mathrm{~g} / \mathrm{cm}^{3}$.

\section{SDS-PAGE OF CIC PREPARATIONS}

CIC were isolated from patients with AS or from blood donors by sucrose gradient ultracentrifugation and subjected to SDS-PAGE. The protein bands were visualised by staining with silver (Figs 2 and 3 ). In all cases a very complex pattern of protein bands was observed. The major protein bands were present in CIC from patients and blood donors. Several minor protein bands, however, were detectable only in CIC from patients with AS. As indicated in Fig. 2 the migration of these components corresponded for two of the proteins to an $\mathrm{M}_{\mathrm{r}}$ of 14-14.5 kD and for one to an $M_{r}$ of $19 \mathrm{kD}$. In addition, a $70 \mathrm{kD}$ component was detected in four out of six patients but not in any of the blood donors (Fig. 3). Proteins

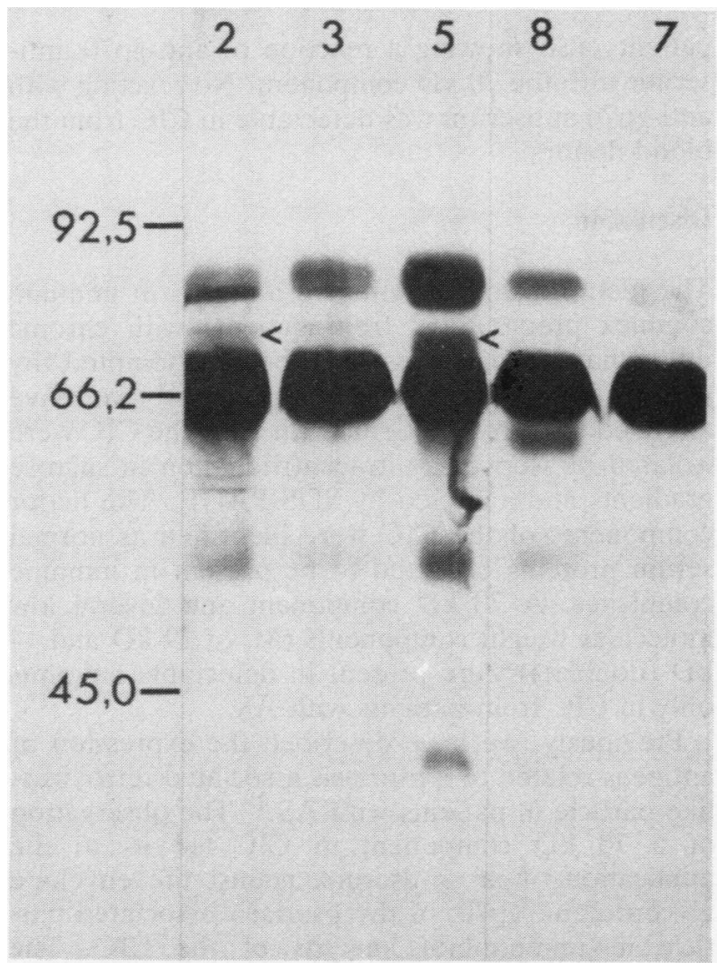

Fig. 3 SDS-PAGE of CIC from patients with AS (lanes 2, 3 , and 5) and blood donors (lanes 7 and 8). The polyacrylamide gel was stained with silver. Arrows indicate a $70 \mathrm{kD}$ component detectable in CIC from patients with with $\mathrm{M}_{\mathrm{r}}$ of 45,42 , and $22 \mathrm{kD}$ were more prominent in $\mathrm{CIC}$ from the patients than from the controls (Fig. 2). Staining with Coomassie brilliant blue after the staining with silver did not reveal any additional components.

\section{M M U NOB L OT T IN G}

For the identification of the components of the CIC, CIC from the patients were pooled, the proteins separated by SDS-PAGE, transferred electrophoretically to nitrocelluose membranes, and blotted with various antisera against normal human serum proteins. As shown in Fig. 4 the major protein bands reacted with antisera against albumin, $\mu$ chain, $\alpha$ chain, and $\gamma$ chain. The protein bands corresponding to kappa and lambda light chains and

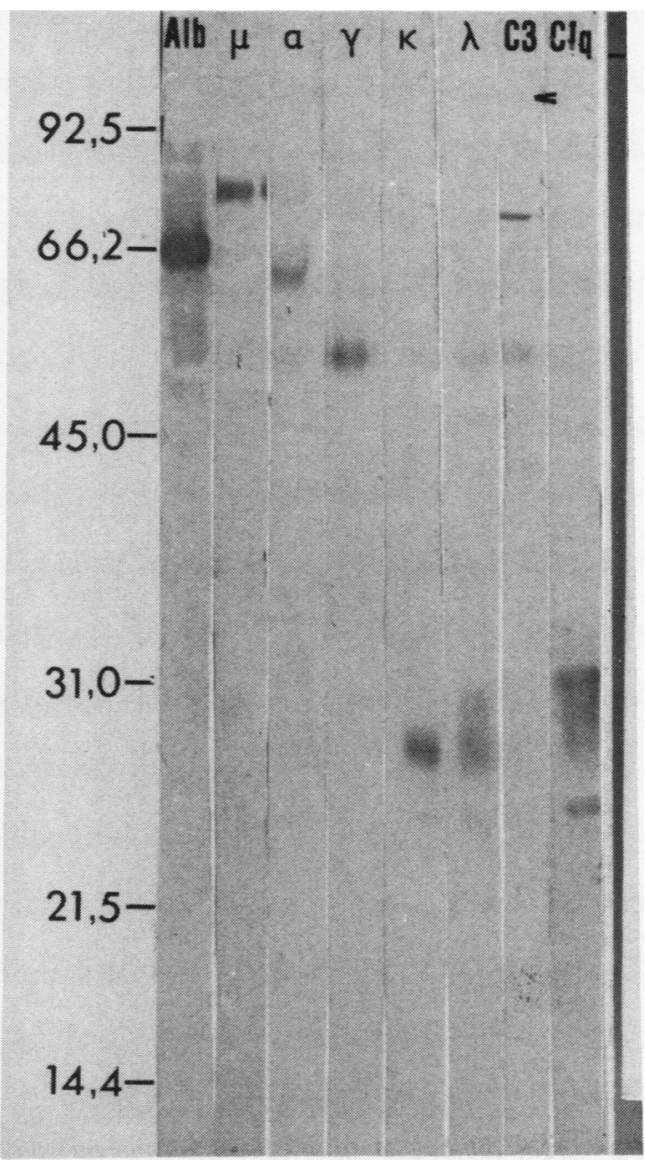

Fig. 4 Immunoblot analysis of pooled CIC from patients with $A S$. The strips were incubated with antisera against albumin (Alb), IgM ( $\mu$ chain $(\mu)), \operatorname{Ig} A(\alpha$ chain $(\alpha)), \operatorname{Ig} G$ (Fc fragment $(\gamma)$ ), kappa light chains $(x)$, lambda light chains ( $\lambda$ ), C3, and C19. Arrow indicates the $95 \mathrm{kD}$ component of activated C3. 
the polypeptides of activated $\mathrm{C} 3$ and $\mathrm{C} 1 \mathrm{q}$ were also identified by this procedure. Antiserum against $\beta_{2}$ microglobulin showed a faint reaction with a protein with an $\mathbf{M}_{\mathrm{r}}$ of approximately $12 \mathrm{kD}$, while no reaction was observed with antisera against CRP or fibrinogen (data not presented).

As indicated in Fig. 3 a $70 \mathrm{kD}$ protein was detected in CIC from patients with AS. An antiserum raised against the envelope glycoprotein, gp70, of a psoriasis associated retrovirus-like particle was applied to check for cross reacting activity. In three out of six patients $(1,4$, and 5) the anti-gp70 antiserum reacted with a $70 \mathrm{kD}$ component (Figs 5 and 6). In addition, the anti-gp70 antiserum also reacted with a component with an $\mathrm{M}_{\mathrm{r}}$ of $40-45 \mathrm{kD}$. This component was present only in CIC from the

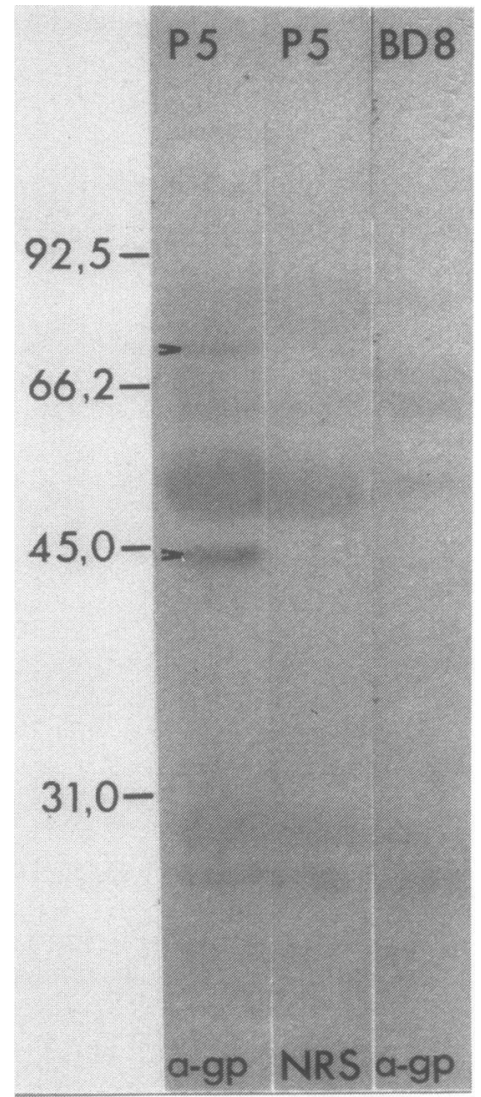

Fig. 5 Immunoblot analysis of CIC from a patient with $A S$ $(P 5)$ and a healthy blood donor (BD 8). The strips were incubated with antiserum against the envelope glycoprotein, gp70, of a psoriasis associated retrovirus-like particle (a-gp) or normal rabbit serum (NRS). Arrows indicate a $70 \mathrm{kD}$ and $a$ 40-45 $k D$ component reacting with the anti-gp 70 antiserum.

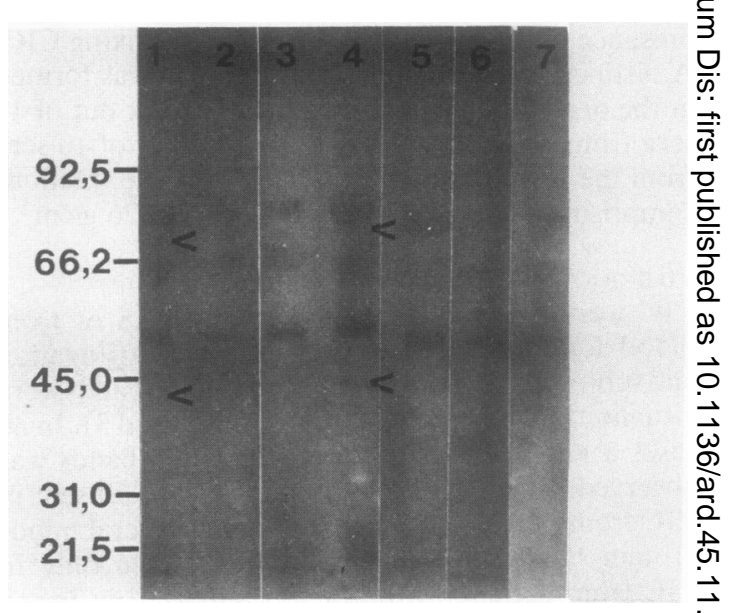

Fig. 6 Immunoblot analysis of CIC from patients with AS (lanes 1-5) and healthy blood donors (lanes 6 and 7). The strips were incubated with anti-gp70 antiserum. Arrows indicate the $70 \mathrm{kD}$ and $40-45 \mathrm{kD}$ components reacting with the anti-gp70 antiserum.

patients also showing a reaction of anti-gp70 antiserum with the $70 \mathrm{kD}$ component. No reaction with

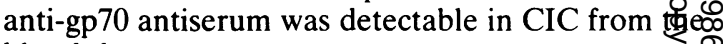
blood donors.

\section{Discussion}

The identification of tentative antigens in immuneo complex preparations from patients with chronic inflammatory disorders has been attempted by several investigators. ${ }^{46}$ In this report we haves analysed CIC from patients with AS. The CIC were isolated by isopycnic ultracentrifugation in sucrose्? gradients and analysed by SDS-PAGE. The majok components of the $\mathrm{CIC}$ were identified as norma serum proteins expected to be present in immune complexes. A $70 \mathrm{kD}$ component and several low molecular weight components $\left(\mathrm{M}_{\mathrm{r}}\right.$ of $19 \mathrm{kD}$ and $1 £$ $\mathrm{kD}$ (doublet)) were present in detectable amount only in CIC from patients with AS.

Previously, we have described the expression of antigens related to a psoriasis associated retrovirus? like particle in patients with AS. ${ }^{18}$ The observation of a $70 \mathrm{kD}$ component in CIC led us to the application of an antiserum against the envelope glycoprotein, gp70, of the psoriasis associated par ticle in immunoblot analysis of the CIC. The antiserum reacted with a $70 \mathrm{kD}$ and a $40-45 \mathrm{kB}$ component. In SLE two unidentified component with approximately the same molecular weights? have been detected in CIC. ${ }^{6}$

Antisera against animal retroviral glycoprotein $\bar{\Phi}$ 
may cross react with normal human cell surface components. ${ }^{22} 23$ The reaction of the anti-gp70 antiserum, however, was restricted to $\mathrm{CIC}$ from three of the patients, which indicates that the $70 \mathrm{kD}$ antigen is not a normal cellular component cosedimenting with the $\mathrm{CIC}$ during sucrose gradient centrifugation.

The anti-gp70 antiserum reacted with a $40-45 \mathrm{kD}$ component in addition to a $70 \mathrm{kD}$ component. A 40-45 $\mathrm{kD}$ component has also been detected in particle preparations from the urine of patients with psoriasis. ${ }^{13} 14$ In several animal retroviruses the apoprotein of the $70 \mathrm{kD}$ envelope glycoprotein has a molecular weight of approximately $40 \mathrm{kD} .^{24}$ Thus the $40-45 \mathrm{kD}$ antigen reacting with anti-gp70 antiserum could represent the non-glycosylated form of the $70 \mathrm{kD}$ component. The observation that proteolytic digestion of the $70 \mathrm{kD}$ envelope glycoprotein from primate retroviruses may result in a $40-45$ $\mathrm{kD}$ component $\mathrm{t}^{24}$ may also explain our observations.

The implication of retroviruses in the pathogenesis of chronic inflammatory disorders in animals is well established, ${ }^{25}$ and retroviral envelope antigens have been detected in immune complexes. ${ }^{1126} 27$ In humans, antigens related to a retrovirus from a human embryonal lung cell line have been detected in glomeruli of patients with SLE ${ }^{28}$ Recently, we have described the isolation of a retrovirus-like particle from a patient with psoriasis and suggested a possible role of particle antigens in the pathogenesis of psoriasis. ${ }^{12-17}$ Antigens related to the major internal protein, p27, of the particle are expressed in patients with psoriatic arthritis, seronegative rheumatoid arthritis, and ankylosing spondylitis. ${ }^{1819}$ Immune reactions are important in the pathogenesis of chronic inflammatory disorders caused by retroviruses. ${ }^{1129}$ Recently, immune reactions against HTLV-I have been suggested to be responsible for the development of tropical spastic paraparesis. ${ }^{30}$ The neurological symptoms observed in patients with acquired immune deficiency syndrome have been attributed to immune reactions against brain cells expressing viral antigens. ${ }^{31}$ In HTLV-I infections, viral antigens have been detected in CIC. ${ }^{32}$

The identification of a $70 \mathrm{kD}$ component reacting with anti-gp70 antiserum in CIC preparations from patients with AS indicates that antigens related to the psoriasis associated retrovirus-like particle may participate in immune reactions in AS and may be implicated in inflammatory reactions in affected tissues.

This work was supported by grants from the Norwegian Society for Fighting Cancer, the Syntex Rheumatology Fund, and Dr Trygve Gythfeldt's Fund. ER is a research fellow of the Norwegian Council for Science and the Humanities. The technical assistance of
Mrs L Carlsson and the generous help offered by Dr $\emptyset$ Romberg in providing the clinical specimens are greatly appreciated.

\section{References}

1 Theofilopoulos A N, Dixon F J. Immune complexes in human diseases. Am J Pathol 1980; 100: 531-91.

2 Rødahl E, Iversen O-J, Dalen A B. Preparative isolation of immune complexes from serum by sucrose gradient ultracentrifugation. Scand J Immunol 1984; 20: 21-6.

3 Espinoza L R, Gaylord S W, Bocanegra T S, Vasey F B, Germain B F. Circulating immune complexes in the seronegative spondylarthropathies. Clin Immunol Immunopathol 1982; 22: 384-93.

4 Maire M A. Barnet M, Carpentier N, Miescher P A, Lambert $\mathrm{P}-\mathrm{H}$. Identification of components of IC purified from human sera. I. Immune complexes purified from sera of patients with SLE. Clin Exp Immunol 1983; 51: 215-24.

5 Male D. Roitt I M, Hay F C. Analysis of immune complexes in synovial effusions of patients with rheumatoid arthritis. Clin Exp Immunol 1980; 39: 297-306.

6 Per S R, Abruzzo J L. Heimer R. Analysis of immune complexes by two-dimensional gel electrophoresis. Clin Immunol Immunopathol 1985; 34: 165-73.

7 Munthe E. Natvig J B. Complement-fixing intracellular complexes of IgG rheumatoid factor in rheumatoid plasma cells. Scand J Immunol 1972; 1: 217-9.

8 Crawford T B, Adams D S. Cheevers W P, Cork L C. Chronic arthritis in goats caused by a retrovirus. Science 1980; 207: 997-9.

9 Pedersen N C, Pool R R, O’Brien T. Feline chronic progressive polyarthritis. Am J Vet Res 1980; 41: 522-35.

10 LeMing Hang. Theofilopoulos A N, Dixon F J. A spontaneous rheumatoid arthritis-like disease in MRL/1 mice. $J$ Exp Med 1982; 155: 1690-701.

11 Izui S, McConahey $\mathbf{P} \mathbf{J}$, Theofilopoulos A N, Dixon F J. Association of circulating retroviral gp70-anti-gp70 immune complexes with murine systemic lupus erythematosus. $J$ Exp Med 1979; 149: 1099-116.

12 Dalen A B, Hellgren L, Iversen O-J, Vincent J. A virus-like particle associated with psoriasis. Acta Pathol Microbiol Immunol Scand $|B|$ 1983; 91: 221-9.

13 Iversen O-J, Dalen A B. Urine proteins cross-reacting with antiserum against virus-like particles from cultured psoriatic epithelial cells. Acta Pathol Microbiol Immunol Scand [B] 1983; 91: 343-9.

14 Iversen $\mathrm{O}-\mathrm{J}$. Isolation of virus-like particles in urine from a psoriatic patient. Acta Pathol Microbiol Immunol Scand [B] 1983; 91: 407-12.

15 Iversen O-J, Dalen A B. The major internal protein, p27, of a retrovirus-like particle is expressed in blood lymphocytes from psoriatic patients. Arch Virol 1985; 85: 197-207.

16 Iversen O-J, Rødahl E. The major internal protein, p27, of a retrovirus-like particle participates in immune complex formation in psoriasis. Arch Virol 1985; 86: 37-45.

17 Iversen O-J, Rødahl E, Dalen A B. The major internal protein, p27, of a psoriasis-associated retrovirus-like particle is expressed in psoriatic skin. Arch Virol 1985; 86: 341-6.

$18 \mathrm{R}$ dahl E, Iversen $\mathrm{O}-\mathrm{J}$. Antigens related to the major internal protein, p27, of a psoriasis associated retrovirus-like particle are expressed in patients with chronic arthritis. Ann Rheum Dis 1985; 44: 761-5.

19 Rødahl E. Isopycnic ultracentrifugation of immune complexes. Scand J Immunol 1985; 21: 93-8.

20 Rødahl E. Problems in the detection of complement-fixing immune complexes. Acta Pathol Microbiol Immunol Scand [C] 1985; 93: $125-30$.

21 Laemmli U K. Cleavage of structural protein during the assembly of the head of bacteriophage T4. Nature $1970 ; 227$ : 681-5. 
22 Markenson J A, Snyder H W. Reactivity of antisera to endogenous primate retrovirus with a human $\mathrm{T}$ cell membrane protein: recognition of a nonviral glycoprotein by antibodies directed only against carbohydrate components. J Immunol 1984; 132: 772-9.

23 Sparrow R L, Purcell D F J, McKenzie I F C. Cross-reactivity of a normal human cell surface antigen with primate retrovirus glycoproteins. Hum Immunol 1985; 13: 83-93.

24 Dickson C, Eisenman R, Hung Fan, Hunter E, Teich N. Protein biosynthesis and assembly. In: Weiss $R$, Teich $N$, Varmus H, Coffin J, eds. RNA tumour viruses. New York: Cold Spring Harbor Laboratory, 1982: 513-648.

25 Teich N, Wyke J, Tak Mak, Bernstein A, Hardy W. Pathogenesis of retrovirus-induced disease. In: Weiss $R$, Teich $N$, Varmus $\mathrm{H}$, Coffin J, eds. RNA tumour viruses. New York: Cold Spring Harbor Laboratory, 1982: 785-998.

26 McGuire T C, Crawford T B, Henson J B. Equine infectious anemia: detection of infectious virus-antibody complexes in the serum. Immunol Commun 1972; 1: 545-51.

27 Tucker D F, Begent R H J, Hogg N M. Characterization of immune complexes in serum by adsorption of staphylococcal protein A: model studies and application to sera of rats bearing a gross virus-induced lymphoma. J Immunol 1978; 121: 1644 o 51.

28 Panem S, Reynolds J T. Retrovirus expression in normal and $\overrightarrow{\overline{\vec{A}}}$ pathogenic processes of man. Fed Proc 1979; 38: 2674-8.

29 Weiss R A, Frisby D P. Are avian endogenous viruses pathogenic? In: Yohn D S, Blakeslee J R, eds. Advances in $\bar{\sigma}$ comparative leukemia research 1981. Amsterdam: Elsevicr/ $\overline{\bar{S}}$ North Holland, 1982: 303-11.

30 Gessain A, Vernant J C, Maurs L, et al. Antibodies to human T-lymphotropic virus type-I in patients with tropical spastic paraparesis. Lancet 1985; ii: 407-10.

31 Levy J A, Hollander H, Shimabukuro J, Mills J, Kaminsky L. $\vec{\circ}$ Isolation of AIDS-associated retroviruses from cerebrospinal $\rightarrow$ fluid and brain of patients with neurological symptoms. Lancet $\vec{\omega}$ 1985; ii: $586-8$.

32 Schüpbach J, Sarngadharan M G, Blayney D W, Kalyanaraman V S, Bunn P A, Gallo R C. Demonstration of viral antigen p 24 ?을 in circulating immune complexes of two patients with human T- $f$ cell leukaemia/lymphoma virus (HTLV) positive lymphoma. Lancet 1984; i: 302-4. 